ing to a changed risk of complications. With such an approach a prospective short term study in a limited number of patients will yield valuable information for longer trials.

In the present study no significant changes in antithrombin III concentrations occurred during treatment with a depot preparation of an agonist of luteinising hormone releasing hormone. This indicates that the treatment does not aggravate the risk of thromboembolism in the same way as oestrogens do. Limited clinical observations also suggested that treatment with the agonist is associated with fewer undesirable cardiovascular side effects than treatment with oestrogens. ${ }^{5}$ There are probably no indications for stopping treatment with the agonist before major surgery, as is recommended with oestrogen treatment.

1 Veterans Administration Cooperative Urological Research Group. Treatment and survival of patients with cancer of the prostate. Surg Gynecol Obstet 1967;124:1011-7.

2 Tolis G, Menta A, Kinch R, Comaru-Schally AM, Schally AV. Suppression of sex steroids by an LH-RH analogue in man. Clin Res 1980;28:676.

3 Varenhorst E, Wallentin L, Risberg B. The effects of orchidectomy, oestrogens and cyproterone acetate on the antithrombin-III concentration in carcinoma of the prostate. Urol Res 1981;9:25-8.

4 Henny CP, ten Cate H, Dabhoiwala NF, Büller HR, ten Cate JW. Effect of hormonal manipulation on antithrombin III activity in patients with prostatic carcinoma. Eur Urol 1984;10:202-6.

5 Trachtenberg J. The treatment of metastatic prostatic cancer with a potent luteinizing hormone releasing hormone analogue. I Urol 1983;129:1149-52.

(Accepted 16 fanuary 1986)

Departments of Urology and Clinical Chemistry, University of Linköping and Central Hospital of Norrköping, Sweden

E VARENHORST, MD, PHD, associate professor of urology

$M$ SVENSSON, $\mathrm{MD}$, senior registrar

H HJERTBERG, MD, senior registrar

E MALMQVIST, MD, senior lecturer in clinical chemistry

Correspondence to: Assistant Professor E Varenhorst, Department of Urology, Central Hospital, S-601 82 Norrköping, Sweden.

\section{Change in skin thickness associated with cheiroarthropathy in insulin dependent diabetes mellitus}

Rosenbloom and Frias described three insulin dependent diabetics who had thick, waxy skin and limited mobility of large and small joints. ' Further studies have shown that the prevalence of limited joint mobility affecting mainly the small joints of the hand (cheiroarthropathy) in insulin dependent diabetics varies from $8 \%$ to $36 \% .^{2}$ The precise cause of this limited joint mobility is not known, but it has been suggested that a structural alteration in collagen may be a factor. ${ }^{2}$ We measured the thickness of the skin in young insulin dependent diabetics using a pulsed ultrasound technique and related the results to the presence of cheiroarthropathy.

\section{Subjects, methods, and results}

Ninety two insulin dependent diabetics aged 20-38 were selected from outpatients regularly attending the diabetic department at this infirmary. The diabetes was of short duration (less than 18 months) in 26 ( 16 men, 10 women) and of longer duration (more than 10 years) in 66 ( 48 men, 18 women). A group of non-diabetic controls comprised 40 healthy volunteers ( 20 men, 20 women) aged 20-38. The thickness of the skin (epidermal surface to interface of dermis and fat) was measured with a Cutech dermal depth detector (Steifel Laboratories, Slough, Berks) using an ultrasound A scan system. ${ }^{3}$ The sites on the skin selected for measurement were the flexor surfaces of both mid-forearms $10 \mathrm{~cm}$ proximal to the distal wrist crease and the medial aspect of both upper arms $10 \mathrm{~cm}$ proximal to the antecubital fossa. The mean of these four measurements was taken as the thickness of the skin of the subject. Limited joint mobility as a measure of cheiroarthropathy was evaluated independently by two observers using the "prayer" manoeuvre outlined by Rosenbloom et al. ${ }^{+}$

The results in the normal subjects and in the groups of patients with diabetes of long and short duration were analysed using Student's $t$ test. The effects of cheiroarthropathy and of duration of diabetes on skin thickness were examined using multiple regression.

Both the men and women with diabetes of long duration had significantly thicker skin compared with the patients with diabetes of short duration $(p<0.001)$ and normal controls $(p<0.001)$ (table). The skin was also significantly thicker in the men with diabetes of short duration compared with the normal controls $(p<0.01)$ and, after allowance was made for duration of disease, in the male diabetics with cheiroarthropathy compared with those without $(p<0.01)$. The women with diabetes were not examined for cheiroarthropathy as there were too few for statistical analysis.

\section{Comment}

Ultrasound A scanning is an accurate and non-invasive technique for measuring thickness of the skin, giving reproducible results. ${ }^{3}$ With this technique skin was shown to be thicker in male and female insulin dependent diabetics. Thickness also increased with duration of diabetes and in men was closely related to cheiroarthropathy.

The pathogenesis of the increased skin thickness is uncertain. There are several reports of defects in connective tissue in patients with diabetes mellitus. It has been suggested that once secreted, collagen is slowly glycosylated, initially reversibly, and then undergoes an irreversible Amadori rearrangement. Further glycosylation results in the accumulation of end products that increase cross linkage of collagen and decrease its susceptibility to in vivo proteolysis. Alternatively, other mechanisms that alter the synthesis, deposition, and catabolism of collagen might contribute to the thicker skin observed in the diabetics of long standing in our study and underlie similar changes in connective tissue at other sites such as periarticular tissue, resulting in cheiroarthropathy. Whether such changes in subcutaneous tissue affect the kinetics of absorption of insulin and whether abnormalities of collagen play a part in other complications of diabetes remain unresolved.

We thank Mrs Linda McDonald for preparing this manuscript and Mrs Cecilia McIntyre of the medical computing and statistics unit, University of Edinburgh, for statistical advice.

1 Rosenbloom AL, Frias JL. Diabetes mellitus, short stature and joint stiffness -a new syndrome Clin Res 1974;22:91. (Abstract.)

2 Lyons TJ, Kennedy L. Non-enzymatic glycosylation of skin collagen in patients with type 1 (insulin-dependent) diabetes mellitus and limited joint mobility. Diabetologia 1985;28:2-5

3 Tan CY, Statham B, Marks R, Payne PA. Skin thickness measurement by pulsed ultrasound: its reproducibility, validation and variability. $\mathrm{Br} \mathcal{F}$ Dermatol 1982;106:657-67.

4 Rosenbloom AL, Silverstein HJ, Lezotte DC, Richardson K, McCallum M. Limited joint mobility in childhood in diabetes mellitus indicates increased risk for microvascular disease. $N$ Englf $\mathrm{Med}$ 1981;305:191-4

5 Sternberg M, Cohen-Forterre L, Peyroux J. Connective tissue in diabetes mellitus: biochemical alterations of the intercellular matrix with reference to proteoglycans, collagens and basement membranes. Diabete Metab 1985;11:27-50.

(Accepted 23 fanuary 1986)

Diabetic and Dietetic Department, Royal Infirmary, Edinburgh EH3 9YW

A COLLIER, MRCP, registrar

D M MATTHEWS, MRCP, senior registrar

H A KELLETT, MRCP, lecturer

B F CLARKE, FRCP, consultant physician

Department of Dermatology, Royal Infirmary, Edinburgh

J A HUNTER, FRCP, professor of dermatology

Correspondence to: Dr Collier.

\begin{tabular}{|c|c|c|c|c|c|c|}
\hline & \multicolumn{3}{|c|}{ Men } & \multicolumn{3}{|c|}{ Women } \\
\hline & No & $\begin{array}{c}\text { Age } \\
\text { (years) }\end{array}$ & $\begin{array}{l}\text { Skin thickness } \\
\qquad(\mu \mathrm{m})\end{array}$ & No & $\begin{array}{c}\text { Age } \\
\text { (years) }\end{array}$ & $\begin{array}{l}\text { Skin thickness } \\
(\mu \mathrm{m})\end{array}$ \\
\hline $\begin{array}{l}\text { Normal subjects } \\
\text { Patients with diabetes: }\end{array}$ & 20 & $27 \cdot 3(4 \cdot 4)$ & $1073(110)$ & 20 & $27 \cdot 9(4 \cdot 7)$ & $918(91)$ \\
\hline Of short duration ( $<18$ months) & 16 & $27 \cdot 5(6 \cdot 7)$ & $1183(92)$ & 10 & $25 \cdot 7(4 \cdot 1)$ & $974(101)$ \\
\hline Of long duration ( $>10$ years) & 48 & $29 \cdot 5(5 \cdot 7)$ & $1396(167)$ & 18 & $26 \cdot 9(5 \cdot 1)$ & $1186(144)$ \\
\hline With cheiroarthropathy* & 17 & $30 \cdot 5(6 \cdot 1)$ & $1522(160)$ & & & \\
\hline Without cheiroarthropathy & 31 & $28.5(4.9)$ & $1326(168)$ & & & \\
\hline
\end{tabular}

